\title{
Determinants of Share Price of Listed Firms in Ghana
}

\author{
Alhassan Musah*, Margaret Aryeetey ${ }^{* *}$ \\ *Academic City College, Accra. P.O.Box AD421, Accra. Property No. 279-302, Haatso, Ghana \\ e-mail: alhassan.musah@acity.edu.gh \\ ** National Communication Authority and Graduate Student, University of Ghana. Box LG25, Legon, \\ Accra, Ghana \\ e-mail: margaret.aryeetey@nca.org.gh
}

DOI: 10.51865/EITC.2021.01.06

\begin{abstract}
The price of a company's share represents investors' confidence in the future profitability of the company and also used to represent the value of shareholders' wealth The study examined factors that influence share price of firms listed on the Ghana stock Exchange. The study specifically examined firm specific factors, book ratios and macroeconomic factors that influence share price of listed firms in Ghana. The firm-specific variables include firm size and the firm being a financial institution. The book ratios used in the study include earnings per share, debt ratio, return on assets, return on equity and dividend per share. The macroeconomic variables include economic growth, inflation rate and interest rate. The study sampled 21 firms over a 10-year period, from 2009 to 2018. The study used descriptive statistics, correlation analysis and panel regression analysis to achieve the objectives of the study. The results of the study show that firm-specific variables such as firm size and the firm being financial institution were positive and statistically significant determinants of share price of listed firms in Ghana. The book ratios of debt to asset ratio, return on asset and return on equity were statistically insignificant association with share price of firms listed on the Ghana Stock Exchange. Other book ratios, such as earnings per share and dividend per share, were positively associated and statistically significant with share price of the sampled firms listed on the Ghana Stock Exchange. On the macroeconomic variables, only economic growth was positively associated with share price and statistically significant at $10 \%$ significance level. The other variables - inflation and interest rate - were statistically insignificant. The results show that book or investment ratios are the main determinants of share price for firms listed on the Ghana Stock Exchange.
\end{abstract}

Keywords: share price; listed firms; firm variables; macroeconomic variables.

JEL Classification: C32; C38; G11; G12; G21; G22.

\section{Introduction}

Research has established that stock markets play an important role in every economy, especially in facilitating the availability of capital to businesses for growth and expansion (Aveh \& Awunyo-Vitor, 2017; Duy et al., 2017; Enow \& Brijlal, 2016; Gatua, 2013). The development is that capital market and the performance of the stock exchange have been linked to economic growth in some countries (Modal \& Imran, 2010). This is because access to capital is one of the major challenges businesses face, especially in developing countries like Ghana where cost of debt finance is very high because of high interest rate. The stock market is very important in this 
context because it provides the medium for the issue and trading of shares which ultimately determine share prices of companies. The stock market also contributes to the trading of instruments other than equity stock such as bonds, debentures and other financial instruments (Atchyuthan, 2017; Wadud, 2017). The price of assets like shares is influenced by market perception which is also based on a number of considerations like a firm's own financial performance, the performance of the general economy, as well as a firm's track record of offering good returns to its investors (Enow \& Brijlal, 2016; Sanju et al., 2011; Bhattarai, 2014).

Share price and its changes are very important in the finance literature as they are considered the most important indicators of firm performance and are the only credible measure of shareholders' wealth (Singh, 2018). This means that share price is very important to both internal and external users of financial information. The performance of companies in an economy is very important to promoting economic growth and prosperity for the citizens of the country (Sunde \& Sanderson, 2009). Economic indicators such as per capita income, employment generation and other economic variables are dependent on firm performance in every economy (Singh, 2018). The share price of a company changes to reflect its performance or investors' perception about the future performance of the company, as well as the general economic outlook of the country. The decision of an investor to buy shares in a company and the timing of such decision is based on the share price of the company (Ghimire \& Mishra, 2018). Rational investors are motivated to invest in companies with strong financial performance, or a growing company. The value of a company is reflected in its share price which also reflects investors' confidence about the performance of the company.

The literature in the area has shown that a considerable amount of research has been conducted on factors that affects share price of listed firms in various parts of the world (Singh, 2018; Baah \& Tawiah, 2014). These studies have focused on different aspects of the factors that affect share price, including internal or firm-specific factors, market and accounting ratios as well as external factors such as macroeconomic variables that explain the share price of companies (Singh, 2018; Atchyuthan, 2017; Duy \& Daang, 2017; Aveh \& Awunyo-Vitor, 2017; Enow \& Brijlal, 2016; Bhattarai, 2014; Baah \& Tawiah, 2014; Asamoah, 2010; Sunde \& Sanderson, 2009; Khan, 2012; Arshad et al., 2014; Ghimire \& Mishra, 2018). The majority of these studies focused on a particular factor that influences share price without combining all the internal and external factors including the book ratios in their analysis. Moreover, the results of these studies are inconclusive with the findings from the studies being contradictory which could be attributed to differences in capital market efficiency in the particular markets used for the studies. For instance, some studies reported that determinants of share price include book value of share, earnings per share, dividend per share, and economic growth or gross domestic product (Ghimire \& Mishra, 2018; Arshad et al., 2014; Aveh \& Awunyo-Vitor, 2017; Khan, 2009; Somoye et al., 2009; Uddin, 2009). The direction of the influence which is either positive or negative varies from one study to another. For example, Enow \& Brijlal (2016) reported an insignificant association between dividend per share and the price of share of companies listed on the Johannesburg stock Exchange while a majority of the studies above found a significant association between the two.

In Ghana some studies have been conducted on specific factors that influence share price of Ghanaian firms. Baah \& Tawiah (2014) in their study examined factors that influence dividend policy and how dividend policy affects share price of listed firms in Ghana. The study reported a weak and statistically insignificant relationship between dividend payout and share price of listed firms in Ghana. Aveh \& Awunyo-Vitor (2017) examined firm-specific determinants of share price after the adoption of IFRS in Ghana. Their study reported that earnings per share, book value and market capitalization and return on equity are significant determinants of share price in Ghana. Adam \& Tweneboah (2010) found that in the short run, inflation and exchange rate influence the stock market price in Ghana. The above review of the literature in Ghana shows that just a little has been done in the area of comprehensively examining factors that 
influence share price of listed firms in Ghana from all the various factors applied in other markets. This study addresses this discrepancy in the literature by examining the influence of book ratios, firm specific variables and macroeconomic indicators on share price of listed firms in Ghana.

\section{Empirical Review}

Equity capital is one of the main sources of finance for corporations, whether small or large (Enow \& Brijlal, 2016). Companies that want to raise capital through stock issue must demonstrate string and consistent financial performance or show great prospects which the capital to be raised will bring to the firm (Singh, 2018; Atchyuthan, 2017). This is mostly the case for an already listed firm which wants to raise additional capital through share issue, even though in Initial Public Offerings (IPOs), the firm's historical performance also contributes to the success of the IPO. Important stakeholders of the company such as creditors, shareholders, employees, management, and government and its agencies all see rising share price as a good indicator of management performance. The share price of companies, according to the literature, is influenced by company-specific variables as well as market-related variables which also have some relations with theories explaining share price of firms (Singh, 2018). Equity investment also provides benefits to investors in the form of dividend, capital gains as well as serves as a form of ownership and control in a firm (Enow \& Brijlal, 2016)

The efficient market hypothesis is one of the theories that have been used in previous studies involving the price of shares. The theory argues that rational investors in any financial market react to available information about a company such as the fundamentals of the company or other declarations that affect the company in their decision when buying or selling their stocks (Baah \& Tawiah, 2014; Asamoah, 2010; Adam \& Tweneboah, 2008). If investors evaluate the company's fundamentals and its information and they feel it is positive, they will retain the shares of the company but if it is negative, they will likely sell the shares to cut their losses (Singh, 2018). The decision and subsequent actions of investors in buying and selling shares of companies determine the share price of the companies at the end of the day. Other theories that have been used to help explain share price movement include the random walk theory, behavioral finance theory, Gorden dividend model among others (Singh, 2018). All these theories, in one way or the other, give explanations to factors that influence the share price of companies.

Several studies have directly examined factors that influence share price of listed firms in various countries (from developing, emerging to developed economies). These studies have either examined industry and firm specific factors that influence share prices of listed firms or relied on macroeconomic factors as potential determinants of share price of listed firms. Some studies have rather focused on the effect of dividend payout on share price of listed firms in various countries. Some of these studies have presented their analysis in line with theories such as the dividend discounted model, the capital assets pricing model and the arbitrage pricing theory as discussed in the previous section. The majority of the papers, however, did not rely on any theoretical underpinning in examining factors that influence share price of firms. This section of the literature review focuses on empirical review of the literature on firm specific and industry specific variables that influence share price of listed firms. It also presents specific financing and accounting ratios that influence share price of listed firms. Finally, it presents an empirical review of the literature on macroeconomic factors that influence share price of listed firms in Ghana.

Avdalović (2018) examined the effect of firm specific factors in share price of listed firms of the Belgrade Stock Exchange. The study was based on a sample of 19 listed firms over a sevenyear period from 2008 to 2014 . The study included firm-specific variables such as firm size, 
return on assets and return on equity, book value of the company, trust rate and other market and financial ratios as potential determinants of share price. The results of the regression analysis showed that firm size, book value of equity, as well as trust, which was measured using the ratio of debt to equity ratio, showed a positive and significant relationship with share price. The study also found evidence of a positive and significant association between return on assets and share price of listed firms on the Belgrade Stock Exchange. Market and investment rations included in the study are price to earnings ratio, earnings per share, etc. The results show that earnings per share and price to earnings ratio are not significant determinants of share price. Arshad et al. (2015) examined determinants of share of listed commercial banks in Pakistan. The study is based on a sample of 22 listed commercial banks in Pakistan over a seven-year period from 2007 to 2013. The study mainly used macroeconomic variables as potential determinants but included firm-specific variables such as leverage as well as other market and financial ratios. The study reported a positive but statistically insignificant association between leverage and share price of listed commercial banks in Pakistan, suggesting that leverage is not a significant determinant of share price of listed banks in Pakistan. The results of the panel regression analysis revealed that there was a negative and statistically significant relationship between interest rates and share price while economic growth measured by GDP growth rate showed a positive but statistically insignificant relationship with share price of commercial banks listed in Pakistan. Aveh \& Awunyo-Vitor (2017) in their study examined firm-specific variables that influence share price of listed firms in Ghana. The study collected data from secondary sources relying mainly on data from the financial statement of listed firms over a seven-year period from 2008 to 2014. The study relied on panel regression model where data was analyzed using random effect panel regression model to achieve the objectives of the study. The study included firm specific variables such as firm size, the leverage of the firm, return on assets and book value of equity in addition to some market and investment ratios that determine share price of listed firms. The results showed that book value of equity, firm size, and returns on equity were significant determinants of share price of listed firms in Ghana as they showed a positive and significant relationship with share price. However, leverage showed a positive but statistically insignificant association with share price of firm listed on the Ghana Stock Exchange. Gill et al. (2012) in their study examined determinants of equity share price of listed firms in America. Their study was based on a sample of 800 American firms over a three-year period from 2009 to 2011. The study included firm-specific variables such as firm size and book value of equity in addition to other market ratios as potential determinants of equity share price in America. The results of the study showed that book value of equity shares as well as CEO duality were significant firm-specific determinants of share price of listed firms in America. Khan (2012) studied the determinants of share price of listed firms on the Karachi Stock Exchange. The study was based on a sample of 34 firms over a 10-year period from 2000 to 2009. The variables examined in the study were mainly market and investment ratios as well as macroeconomic variables with few firm specific variables such as book to market value. The study found a positive and significant relationship between book to market ratio and share price of listed firms on the Krachi Stock Exchange. Singh (2018) examined determinants of stock price of listed firms in Muscat securities market in Oman. The study sampled 26 listed firms in Oman over a six-year period from 2011 to 2016. The study relied on market and investment ratios as potential determinants of stock price as well as some macroeconomic variables but included firm size measured by the natural logarithm of total assets. The study relied on the efficient market hypothesis theory and the arbitrage pricing theory to examine the factors that influence share prices in Oman. The regression analysis showed that the size of a firm is not a significant determinant of share price of listed firms in Oman. Bhattarai (2014) examined factors that determine share price of listed commercial banks in Nepal. The study was based on a sample of 11 commercial banks listed on the Nepalese Stock Exchange over a 9-year period from 2006 to 2014. The study was based on secondary data extracted mainly from the financial statement of the sampled commercial banks. The study was based on market and investment ratios as potential determinants of share price but also included firm size as one of the potential 
factors that influence share price. The results of the study showed that firm size even though had positive relationship with share price was statistically insignificant. Enow \& Brijlal (2016) examined determinants of share price of listed firms on the Johannesburg Stock Exchange. The study extracted data from a secondary source, mainly from financial statement of the firms over a five-year period from 2009 to 2013 . The study used market ratios as well as some other firmspecific variables such as return on assets, return on equity and firm size. The study, however, did not find evidence that these factors did not have significant influence on share price. Atchyutha (2017) in a related study examined determinants of share price of listed manufacturing firms in Sri Lanka. The study sampled 25 listed firms over a 5-year period from 2012 to 2016. The study used various market and investment ratios as well as firm-specific variables such as return on assets, return on equity and debt to assets ratio. The study found that these entire firm-specific variables had positive relationship with share price but were statistically insignificant. Ghimire \& Mishra (2018) examined factors that determine share price of listed firms in Nepal. The study relied on market and investment ratios as potential determinants of share price with variables such as dividend per share, earnings per share, price to earnings ratio and market to book value ratio. The study was based on a sample of 11 financial and nonfinancial firms covering a six-year period from 2012 to 2017 . The results of the regression analysis showed that market value to book value, price to earnings ratio, dividend per share and book value of share are significant determinants of share price of listed firms in Nepal. The study, however, found that earnings per share were not a significant determinant of share price. Arshad et al. (2015) examined the influence of market ratios as well as macroeconomic variables on share price of listed commercial banks in Pakistan. The study sampled listed commercial banks on the Karachi Stock Exchange over a 7-year period from 2007 to 2013. The study used financial and market ratios as well as macroeconomic variable as potential determinants of share price. The study included market and investment ratios such as earnings per share, dividend per share, price to earnings ratio, etc. The regression results showed that earnings per share have positive and significant association with share price while the other variables were statistically insignificant. Aveh \& Awunyo-Vitor (2017) in their study examined firm-specific variables that influence share price of listed firms in Ghana. The study collected data from secondary sources relying mainly on data from the financial statement of listed firms over a seven-year period from 2008 to 2014 . The study relied on panel regression model where data was analyzed using random effect panel regression model to achieve the objectives of the study. The study included market and investment ratios such as earnings per share, dividend per share and dividend yield. The result showed that earnings per share and dividend yield are significant determinants of share price of listed firms in Ghana where earnings per share had positive relationship while dividend yield had negative relationship with share price. Gill (2012) examined the determinants of equity share price of American firms. The study used a number of market and financial ratios as well as firm specific characteristics as potential determinants of share price of these American firms. The market ratio used in the study included price to earnings ratio, dividend payout ratio, dividend per share, dividend coverage ratio, etc. Their study was based on a sample of 800 American firms over a three-year period from 2009 to 2011. The results of the panel regression showed that earnings per share, dividend per share, price to earnings ratio are significant determinants of share price in America. Khan (2012) studied the determinants of share price of listed firms on the Karachi Stock Exchange. The study was based on a sample of 34 firms over a 10-year period from 2000 to 2009. The study used a combination of financial ratios as well as macroeconomic variable as potential determinants of share price of listed firms on the Karachi Stock Exchange. The study included market ratios such as price to earnings ratio and dividend per share. The results of the analysis showed that dividend per share were a significant determinant of share price while price to earnings ratio was statistically insignificant with share price. Singh (2018) studied the determinants of stock price using a sample of listed firms from Oman. The study used a combination of macroeconomic variables and market ratios as well as firm specific variables to achieve the objectives of the study. The market ratios used in the study as potential determinants of share 
price included dividend payout, earnings per share, and price to earnings ratio. The results of the regression analysis revealed that earnings per share were a significant determinant of share price while dividend payout and price to earnings ratio were statistically insignificant. The results also showed a negative and statistically significant relationship between inflation and share price while oil price showed a positive and statistically significant relationship with share price. The study however found an insignificant relationship between gross domestic product and share price of listed firms in Oman. In a related study, Bhattarai (2014) in a study on determinants of share price of listed firms in Nepal included market ratios such as dividend payout ratio, dividend yield, earnings per share, price to earnings ratio, etc. The regression analysis showed that dividend yield, earnings per share, and price to earnings ratio were significant determinants of share price of listed firms in Nepal. Dividend payout ratio, however, was statistically insignificant. Furthermore, Enow \& Brijlal (2016) in their study on determinants of share price based on a sample of listed firms on the Johannesburg Stock Exchange included market ratios such as dividend payout ratio, earnings per share and price to earnings ratio. The results show that earnings per share and price earnings are significantly positively correlated to share prices although dividend per share was not. Similarly, Atchyuthan (2017) in a study on determinants of share price of listed manufacturing firms in Sri Lanka and included dividend per share and earnings per share. The results revealed that earnings per share and dividend per share are the major determinants of share price. Therefore, investors and fund managers must consider these determinants while taking investment decisions. Oyama (1997), a working paper for the International Monetary Fund (IMF), studied determinants of stock prices of firms in Zimbabwe. The paper focused on macroeconomic variables as potential determinants of share price of the listed firms in Zimbabwe. The study examined macroeconomic variables such as exchange rate, money supply, inflation, interest rate commodity price index among others. The study found a significant relationship between share price and money supply growth as well as Treasury bill rates. The other macroeconomic variables were found to be statistically insignificant in terms of influencing share price of listed firms in Zimbabwe.

Furthermore, Gill et al. (2012) in their study on determinants of equity share price of listed American firms also included macroeconomic variables as potential determinants of share price in Ghana. The study was based on a sample of 800 firms over a 3-year period from 2009 to 2011. The macroeconomic variables included in the model used for the study as potential determinants of share price of these American firms included inflation, economic growth, interest rates, etc. The results of the study did not find evidence of a significant relationship between these macroeconomic variables and share price of the sampled American firms. Duy et al. (2017) in their study about determinants of stock price of joint-stock companies in the industrial sector listed on the Hcm Stock Exchange included a number of macroeconomic variables as potential determinants of share prices of listed firms. The macroeconomic variables examined in the study included exchange rate, gold price, interest rates, among others. The results of the regression and correlation analysis showed that exchange rate and interest rates were positively associated with share price while gold price and inflation were negatively associated with share price. However, it was gold price that was statistically significant with share price of the listed firms. Adam \& Tweneboah (2008) examined macroeconomic variables that influence movement of share price of listed firms in Ghana. The study analyzed both shortterm and long-term relationships between macroeconomic variables and stock market index in Ghana. The study used macroeconomic variables such as foreign direct investment, treasury bills, consumer price index and exchange rate. The study found that there is co-integration between macroeconomic variables and stock prices in Ghana in the long-run. However, in the short-run, inflation and exchange rate are significant determinants of share price in Ghana. 


\section{Research Methodology}

This study is based on the quantitative research design for a number of reasons. First, the study relies on secondary data that are numerical in nature and which require statistical tools for analysis. Second, the study sought to establish the relationship between variables using statistical techniques and as such correlation and regression analyses. The quantitative approach is the only best way to achieve the objectives of the study. The population of the study includes all firms from all industries listed on the Ghana Stock Exchange which include 40 listed firms. The sample technique used to achieve the objectives includes firms that meet the following criteria. First, the firm must be listed on the Ghana stock exchange for the past 10 years as the study sought to use 10-year sample period from 2009 to 2018 . The company must have its financial statement publicly available to enable data collection. Even though all listed firms are required by law to publish their financial statement on their website and the website of the Securities and Exchange Commission Ghana as well as the Ghana Stock Exchange, some companies over the year have not complied with this directive. On the basis of the above criteria, the study used 23 listed firms on the Ghana Stock Exchange.

The study adopted a panel regression model to achieve the objectives of the study. Panel models allow studies in developing countries like Ghana with small sample sizes because of the number of companies in the economy to improve on the sample size which also improves the reliability of the estimates. The empirical model of share price as dependent variable and a number of variables from firm and industry specific variables, book ratios and macroeconomic variables that influence share price of listed firms on the Ghana Stock Exchange. The empirical model adopted for the study is presented below

$$
\begin{gathered}
\text { SharePrice }_{i t}=\beta_{0}+\beta_{1} \text { Size }_{i t}+\beta_{2} D R_{i t}+\beta_{3} F I N_{i t}+\beta_{4} R O A_{i t}+\beta_{5} R O E_{i t}+ \\
\beta_{6} E P S_{i t}++\beta_{7} D P S_{i t}+\beta_{8} G D P_{i t}+\beta_{9} I N F_{i t}+\beta_{10} I N T_{i t}+\varepsilon_{i t}
\end{gathered}
$$

Where:

Share price which is the dependent variable is measured as the average price per share for listed firms in Ghana, ROA which is the return on assets measured as profit before tax divided by total assets, ROE is return on equity which is measured as profit after tax divided by total equity, SIZE represent the size of the firm which is measured as the natural logarithm of total assets, FIN is a dummy variable which is measured as 1 if the firm is financial institution and 0 otherwise, DR is the debt ratio which is measured as total liabilities divided by total assets, EPS is the earnings per share which is measured as profit attributable to equity holders divided by the number of share outstanding, GDP measured the economic growth of the country, INF represent inflation and measured as the average inflation rate as reported by the Bank of Ghana and finally, INT represent interest rate which is the average interest rate for the year.

\section{Research Findings/Results}

Table 1. Descriptive Statistics

\begin{tabular}{lcccc}
\hline Variable & Mean & Std. Dev & Min & Max \\
\hline Share Price & 7.30 & 13.3486 & 0.01 & 37 \\
LogFirm Size & 7.8956 & 0.7112 & 4.6045 & 9.5175 \\
Debt Ratio & 0.8875 & 2.9877 & 0.0629 & 21.1263 \\
FIN & 0.3645 & 0.7645 & 0 & 1 \\
ROA & 0.0449 & 0.3447 & -1.4216 & 1.002 \\
ROE & 0.0933 & 0.5436 & -2.5303 & 2.0071 \\
EPS & 0.2637 & 0.5043 & -0.1456 & 1.65 \\
Dividend per share & 0.0356 & 0.0449 & 0 & 1.0245
\end{tabular}




\begin{tabular}{lcccc} 
& & & Table 1 (cont.) \\
Economic Growth & 6.6356 & 3.4056 & 2.1782 & 14.047 \\
Inflation & 0.1225 & 0.0353 & 0.067 & 0.1746 \\
Interest Rate & 0.2722 & 0.0232 & 0.2396 & 0.3275 \\
\hline
\end{tabular}

The results from Table 1 show that the average share price of listed firms sampled from the Ghana Stock Exchange is GHC7.30 with the minimum share price over the study period as GHC0.01, while the maximum share price is GHC37. The second variable measured firm size which used the natural logarithm of total assets which range from 4.6 to 9.5 with 7.9 as the mean score. The variables as reported are the natural logarithm of share price to ensure that it does not affect the regression analysis. The next variable measured the proportion of total assets acquired by debt capital. The results from the descriptive statistics show that an average listed firm is financed mainly by debt capital with a mean of $88 \%$. The firms with the least debt capital to total assets ratio has debt to asset ratio of $6 \%$ which suggests that the majority of its assets were financed by equity capital. The next variable was a dummy variable that measured whether the listed firm is a financial institution or not. The results from Table 1 show that $36 \%$ of the firms sampled were financial firms while the remaining ones were not. The next variable examined the return on assets which is a measure of profitability of the listed firms. The results show that the average return on assets over the study period for listed firms is $4.5 \%$. The study further examined the return to equity holders based on the profit earned for the year using return on equity. The results show that the average return on equity over the study period is $9.3 \%$. The next variable from Table 1 measured cedi return to each unit of shares held over the study period. The results show that the average earning per share is GHC0.27 with the maximum earning per share as GHC1.02 and negative GHC0.14 as the minimum. The results also show that the average dividend per share paid over the study period was GHC0.04 per share, the minimum dividend paid being 0 and the maximum being GHC1. The zero minimum figures show that some firms did not pay dividend over the study period.

The last three variables examined macroeconomic variables that were included as potential

factors that affect share price of listed firms in Ghana. The first macroeconomic variable, economic growth, showed an average Gross Domestic Product growth rate of $6.64 \%$ over the study period with the minimum growth rate as $2.18 \%$ and the maximum growth rate as $14.05 \%$. Inflation rate which is the second macroeconomic variable had an average score of $12.25 \%$ over the study period with the highest inflation being $17.46 \%$. The last variable examined the average lending rate as reported by the Bank of Ghana which measured the cost of debt capital in Ghana.

The results show that the average lending rate over the study period is $27.22 \%$ with the minimum lending rate at $23.96 \%$ and the maximum being $32.75 \%$.

Table 2. Correlation Matrix

\begin{tabular}{|c|c|c|c|c|c|c|c|c|c|c|c|}
\hline & $\begin{array}{c}\text { Share } \\
\text { Px }\end{array}$ & Size & DR & FIN & ROA & ROE & EPS & DPS & GDP & INF & INT \\
\hline Share Price & 1 & & & & & & & & & & \\
\hline Firm Size & 0.4262 & 1 & & & & & & & & & \\
\hline Debt Ratio & -0.5745 & -0.0017 & 1 & & & & & & & & \\
\hline FIN & 0.6535 & 0.4562 & 0.5764 & 1 & & & & & & & \\
\hline ROA & 0.298 & -0.0099 & 0.537 & 0.4362 & 1 & & & & & & \\
\hline ROE & 0.12 & -0.3269 & -0.409 & 0.6542 & 0.5033 & 1 & & & & & \\
\hline EPS & 0.819 & 0.1342 & -0.5955 & 0.4865 & 0.3474 & 0.3736 & 1 & & & & \\
\hline DPS & 0.5969 & -0.0028 & -0.4613 & 0.5234 & 0.4906 & 0.4267 & 0.6542 & 1 & & & \\
\hline GDP & 0.0378 & -0.0567 & -0.0972 & 0.0245 & 0.1974 & -0.0625 & 0.0316 & 0.0868 & 1 & & \\
\hline Inflation & -0.0106 & 0.0624 & 0.1215 & 0.3125 & 0.1681 & 0.0048 & -0.0034 & 0.1183 & -0.7234 & 1 & \\
\hline $\begin{array}{l}\text { Interest } \\
\text { Rate }\end{array}$ & 0.0664 & -0.1344 & -0.0388 & 0.4135 & -0.1578 & -0.1397 & -0.0635 & 0.0212 & -0.503 & 0.5654 & 1 \\
\hline
\end{tabular}


The correlation result showed that variable such as FIN, DPS and Debt Ratio has strong correlation with share price while the rest have weak correlation with share price.

Also, the correlation matrix was used to examine the extent of multicollinearity among the independent variables. According the rule of thumb in using correlation matrix to examine multicollinearity, multicollinearity exists where the correlation coefficient between two independent variables exceed 0.8 . The correlation matrix in Table 2 does not have any such correlation coefficient among the independent variables.

\section{Diagnostics and Reliability Test}

\section{Heteroscedasticity Test}

Heteroscedasticity Test evidenced from Breuch-Pagan/ Cook-Weisberg Test to test if there is an evidence of heteroscedasticity. Using the null hypothesis that the residuals are homoscedastic $\left(\mathrm{H}_{\mathrm{o}}=\right.$ constant variance $)$. The rule of the thumb is that, reject the null hypothesis and choose the alternative when the P-value is less than 0.05 . Using Stata "hettest" command, the P-value is 0.4803 which is higher than 0.05 ; hence, we failed to reject the null hypothesis that there is constant variance. Therefore, there is no evidence of heteroscedasticity. The test is reported below as well.

Table 3. Heteroscedasticity test using Breusch-Pagan/Cook-Weisberg Test

\begin{tabular}{|l|l|}
\hline Chi2(1) & 0.50 \\
\hline Prob $>$ chi2 & 0.4803 \\
\hline
\end{tabular}

Source: Authors' construct, 2020.

\section{Multicollinearity Test}

The problem of multicollinearity was confirmed by using the variance inflation factor (VIF) analysis. The VIF is shown in Table 4. The rule of thumb for VIF is that if a variable has a VIF of more than 10, then they are collinear with another independent variable. It can be seen from the table below that all independent variables have a VIF less than 10 which shows absence of multicollinearity between the independent variables.

Table 4. Variance Inflation Factor

\begin{tabular}{lll}
\hline Variable & VIF & 1/VIF \\
\hline DR & 4.4 & 0.2271 \\
ROA & 3.85 & 0.2596 \\
INF & 1.97 & 0.5088 \\
GDP & 1.96 & 0.5097 \\
FIN & 1.75 & 0.6015 \\
INTEREST & 1.55 & 0.6435 \\
LOGSIZE & 1.46 & 0.6865 \\
DPS & 1.27 & 0.7862 \\
ROE & 1.27 & 0.7895 \\
EPS & 1.13 & 0.8817 \\
Mean VIF & 2.1 & \\
\hline
\end{tabular}

Source: Authors' construct, 2020. 
The correlation matrix showed higher correlation coefficient between Debt ratio (DR) and the firm being a financial institution (FIN) with a coefficient of 0.57. Also, the correlation coefficient between DR and DPS was also higher at 0.76 . Even though these values are below the rule of thumb of 0.8 which signifies the presence of multicollinearity, the study further used the variance inflation factor (VIF) to determine the presence of multicollinearity. The result of the VIF analysis as shown in table 4 above suggest that even though DR has the highest VIF of 4.4 , it is still below the level prescribed by the rule of thumb which is 10 . Also, the tolerance value associated with the DR is 0.22 which is above 0.1 and clearly support the earlier assertion that there is no problem with multicollinearity in the model.

\section{Hausman Specification test}

From the test, the P-Value is statistically insignificant at 0.3906 ; hence, we fail to reject the null hypothesis that the random effect is the preferred model. The researcher used the random effect estimator to estimate this model. For better and reliable result of the random effect regression, the robust random effect result is appropriate. This is because robustness filters out other statistical disturbance elements from the result. Thus, the robust random effect of GLS regression result is presented and used to test the hypothesis of the study.

\section{Regression Analysis}

The regression analysis was used to test the hypothesis of the study to answer the objectives of the study. This was after the various diagnostic tests have been done. The study used the random effect robust result to ensure that all disturbances are taken care of. A summary of the regression analysis is done in Table 5 below.

The regression output showed an adjusted R-square of almost $78 \%$ which suggests that the independent variables can explain $78 \%$ of the variations in the dependent variable (share price). The probability of the F-statistic is also statistically significant at $1 \%$ significance level, suggesting that the model is well fit.

Table 5. Random Effect Regression Result

\begin{tabular}{lccc}
\hline \multicolumn{1}{c}{ Variable } & Coefficient & Std.Err & P-value \\
\hline Firm Size & $0.2758^{* *}$ & 0.11980 & 0.015 \\
Debt Ratio & -0.0467 & 0.04460 & -0.355 \\
FIN & $1.2536^{* * *}$ & 0.12500 & 0.000 \\
ROA & 0.1762 & 0.38810 & 0.155 \\
ROE & 0.6736 & 0.90080 & 0.146 \\
EPS & $2.3979^{* *}$ & 1.12290 & 0.015 \\
Dividend per share & $0.6809^{* * *}$ & 0.20633 & 0.000 \\
Economic Growth & $0.9575^{*}$ & 0.4901 & 0.065 \\
Inflation & 8.4839 & 14.58570 & 0.566 \\
Interest Rate & 17.2201 & 19.35060 & 0.374 \\
Cons & 10.1645 & 4.92310 & 0.108 \\
R-Squared & 0.7859 & & \\
Wild Chi 2 (10) & 585.45 & & \\
Prob>Chi2 & 0.000 & & \\
\hline
\end{tabular}

(Note: *** means significant at $1 \%$ significance level; ** means significant at $5 \%$ significance level and * means significant at $10 \%$ significance level) 


\section{Discussion of Findings}

The first objective of the study sought to examine the influence of firm specific variables on share price of firms listed on the Ghana Stock Exchange. The study used firm characteristics such as firm size and whether the firm is a financial institution or not. The correlation matrix and the regression analysis showed that there is a positive relationship between the size of a firm and share price of firms that are listed on the Ghana Stock Exchange. The correlation matrix was statistically significant at 5\% significance level. Consistent with the correlation analysis, the regression analysis was statistically significant and also positively associated with share price. The result means that larger firms generally have higher share price but in terms if predictability, firm size does not significantly influence share price. The result suggests that companies with larger asset size will normally exhibit higher share price though not statistically significant. The result is consistent with the findings of Avdalovic (2018) where the study revealed a positive and statistically significant association between firm size and share price of firms listed on the Belgrade Stock Exchange. The result is also consistent with the findings of Aveh \& Awunyo-Vitor (2017) who reported a positive and significant association between the size of a firm and share price of firms that are listed in Ghana. The result is, however, inconsistent with the findings of Singh (2018) which found a positive but statistically insignificant association between firm size and the share price of firms listed in Oman. The finding is also inconsistent with the findings of Bhattarai (2014) who reported positive and statistically significant relationship between the size of firm and share price on the Nepalese Stock Exchange. The second firm specific variable examined the relationship between a firm being financial institution and share price in Ghana. The analysis shows a positive and statistically significant association between being a financial institution and share price of firms listed on the stock exchange in Ghana. The results of both the correlation matrix and the regression analyses show a statistically significant relationship between being a financial institution and share price in Ghana. The finding is consistent with the general stock analysis forecast in Ghana where financial stocks are the preferred compared to shares of non-financial firms on the Ghana Stock Exchange. The second objective sought to examine the influence of book ratios on share price of listed firms in Ghana. The study used accounting and book ratios such as debt ratio, return on assets, return on equity, earnings per share and dividend per share. The correlation matrix and regression analysis show that there is a negative association between debt ratio and share price of firms listed on the Ghana Stock Exchange. The result shows that the association was statistically insignificant which suggests that debt ratio is not a significant determinant of share price in Ghana. The result suggests that the level of financial risk is not a significant determinant of share price in Ghana. The result is contrary to the findings of Avdalović (2018) who reported a positive and statistically significant association between debt ratio and the price of shares. Also, the result is contrary to the findings of Arshad et al. (2015) who reported a positive but statistically insignificant association between leverage and share price. Similar findings were also reported by Aveh \& Awunyo-Vitor (2017) where the association between the two variables was positive but statistically insignificant.

The next book ratio variable in the model is return on assets. Both the correlation matrix and the regression analysis show that there was a positive association between return on assets and the price of shares of companies which trade their stocks on the Ghana Stock Exchange. The results of the correlation and regression analysis were, however, statistically insignificant which means that profitability measured by return on assets is not a significant determinant of share price in Ghana. The result is consistent with the findings of Atchyutha (2017), Aveh \& Awunyo-Vitor (2017) and Enow \& Brijlal (2016) who found a positive but statistically insignificant relationship between share price and return on assets. The last next book ratio variable also measured the effect of profitability using return on equity and its influence on share price of firms listed in Ghana. The correlation matrix and the regression analysis showed that there is a positive but statistically insignificant association between return on equity and price of shares in 
Ghana. The result is contrary to the findings of Aveh \& Awunyo-Vitor (2017) who reported a significant association between return on equity and share price. The result is consistent with the findings of Enow \& Brijlal (2016) who found a positive and significant association between return on equity and share price of listed firms on the Johannesburg Stock Exchange. The result is also consistent with the findings of Atchyutha (2017) who also reported a positive but statistically insignificant association between return on equity and share price in Sri Lanka. The next book ratio examined the effect of earnings per share on share price of firms listed on the Ghana Stock Exchange. The correlation matrix and the regression analysis show that there is a positive association between earnings per share and share price of listed firms on the stock exchange in Ghana. The association was also statistically significant at $1 \%$ significance level for both the correlation matrix and the regression analysis. The result suggests that earnings per share are a significant determinant of share price in Ghana. The result is contrary to the findings of Nautiyal (2015) who found a positive but statistically insignificant association between earnings per share and share price. Also, Avdalović (2018) reported positive but insignificant association between the two variables. The result is, however, consistent with the findings of Ghimire \& Mishra (2018) who found a positive and significant association between earnings per share and share price. The result is also consistent with the findings of Arshad et al. (2015), Aveh \& Awunyo-Vitor (2017), Gill (2012) and Singh (2018) who found a positive and statistically significant relationship between earnings per share and share price of listed firms in Ghana. The last book variable dividend per share showed a positive and statistically significant association between dividend per share and share price from both the correlation matrix and the regression analysis. The result shows that dividend per share is a significant determinant of share price of firms whose stocks are traded on the Ghana Stock Exchange. The result is consistent with the findings of Ghimire \& Mishra (2018), Gill (2012), Khan \& Amanullah (2012) and Atchyuthan (2017) who found a positive and significant association between dividend per share and share price of firms listed on the Ghana Stock Exchange. The result is contrary to the findings of Nautiyal (2015) who reported a negative association between dividend per share and share price.

The last objective of the study examined the influence of macroeconomic variables on share price of firms whose stocks are listed on the Ghana Stock Exchange. The study included three macroeconomic variables (GDP growth rate which was used to represent economic growth, inflation rate and interest rate which was measured by the lending rate of commercial banks in Ghana). The result shows that there is a positive relationship between economic growth and share price of firms listed on the Ghana Stock Exchange using both the correlation matrix and the regression analysis. The regression analysis showed that the positive association between economic growth and share price is statistically significant at $10 \%$ significance level. The result shows that economic growth is a significant determinant of share price even though the $10 \%$ significance level means it is a weak determinant. The result is consistent with the findings of Nautiyal (2015) and Khan \& Amanullah (2012) who reported a positive and statistically significant association between economic growth and share price in Ghana. The result is contrary to the findings of Arshad et al. (2015) who found a negative and significant association between economic growth and share price. Also, Gill et al. (2012) found insignificant association between economic growth and share price which is contrary to the findings of this study. The second macroeconomic variable - inflation rate - was positive but statistically insignificantly associated with share price based on the correlation matrix and the regression analysis. The result shows that inflation rate is not a significant determinant of share price of listed firms in Ghana. The result is consistent with the findings of Gill et al. (2012) who reported positive but statistically insignificant association between share price and inflation. The result was also contrary to the findings of Duy et al. (2017) and Singh (2018) who reported a negative association between inflation and share price of listed firms in other parts of the world. The last variable examined the effect of interest (lending rate) and share price of firms whose shares are listed on the Ghana Stock Exchange. The result of the study shows that there is a 
positive relationship between interest rate and share price but the association was statistically insignificant. The result shows that inflation rate is not a significant determinant of share price in Ghana. The result is contrary to the findings of Khan \& Amanullah (2012) and Arshad et al. (2015) who reported a negative association between interest rate and share price. Duy et al. (2017) reported a positive and significant association between interest rate and share price. The result is consistent with the findings of Gill et al. (2012) who reported positive but statistically insignificant association between inflation rate and share price.

\section{Conclusion}

The study concludes that firm-specific factors such as firm size and being a financial institution were positive and statistically significant with share price of firms listed on the Ghana Stock Exchange. On the other hand, book ratios such as debt to assets ratio, return on assets and return on equity are not significant determinants of share price of listed firms in Ghana. The study also concludes that book ratios such as earnings per share and dividend per share are significant determinants of share price for companies whose shares are traded on the Ghana Stock Exchange. In terms of macroeconomic variables, only economic growth influences share prices or is associated with higher share prices in Ghana while inflation and interest rate were not significant determinants of share price. Overall, the book ratios used for investment decisions have the most significant influence on share price of listed firms in Ghana.

The study makes significant contributions in the area of share price and stock market research in Ghana by extending the study of Aveh \& Awunyo-Vitor (2017) who focused on only financial ratios to include macroeconomic variables and other firm specific variables that influence share price of listed firms in Ghana. The study therefore contributes to the literature on share price in Ghana and in developing countries with similar stock markets like Ghana. The results of the study will help policy makers understand variables that contribute towards share prices of listed firms in Ghana so they can manage them well. The results will also be useful to managers of listed firms who consistently strive to grow their share price to understand factors that influence the price of their shares in the Ghanaian context.

Recommendations: First, the study recommends that company managers who want to grow their share price should work to improve key book ratio such as earnings per share, dividend per share and price to earnings ratio. Second, Investors who want good performing share should focus on shares of financial institutions as they are associated with higher prices. The study also recommends that future studies can examine other firm specific characteristics such as ownership, long term debt ratio, profit margin, etc.

\section{References}

1. Acquah-Sam, E., \& Salami, K. (2014). Effect of capital market development on economic growth in Ghana. European Scientific Journal, 10(7).

2. Adam, A. M., \& Tweneboah, G. (2008). Do macroeconomic variables play any role in the stock market movement in Ghana?. Available at SSRN 1152970.

3. Adjasi, C. K., \& Biekpe, N. B. (2006). Stock market development and economic growth: The case of selected African countries. African Development Review, 18(1), 144-161.

4. Ali, R., \& Mustafa, U. (2012). External debt accumulation and its impact on economic growth in Pakistan. The Pakistan Development Review, 79-95.

5. Arshad, Z., Arshaad, A. R., Yousaf, S., \& Jamil, S. (2015). Determinants of share prices of listed commercial banks in Pakistan. IOSR Journal of Economics and Finance, 6(2), 56-64.

6. Asamoah, G. N. (2010). The impact of dividend announcement on share price behaviour in Ghana. Journal of Business \& Economics Research, 8(4), 47. 
7. Atchyuthan, N. (2017). Determinants of Share Prices: Evidence From Listed Manufacturing Firms In Sri Lanka. EPRA International Journal of Multidisciplinary Research, 3(6), 63- 68.

8. Avdalović, S. M. (2018). The Impact of Firm Specific Factors on the Stock Prices: Empirical Evidence from Belgrade Stock Exchange. Industry/Industrija, 46(2).

9. Aveh, F. K., \& Awunyo-Vitor, D. (2017). Firm-specific determinants of stock prices in an emerging capital market: Evidence from Ghana Stock Exchange. Cogent Economics \& Finance, 5(1), 1339385.

10. Baah, B. K., Tawiah, R., \& Opoku, F. E. (2014). Industry sector determinants of dividend policy and its effect on share prices in Ghana. International Journal of Economics, Business and Finance, 2(5), 1-19.

11. Beck, T., Demirgüç-Kunt, A., \& Honohan, P. (2009). Access to financial services: Measurement, impact, and policies. The World Bank Research Observer, 24(1), 119-145.

12. Beine, M., \& Candelon, B. (2011). Liberalisation and stock market co-movement between emerging economies. Quantitative Finance, 11(2), 299-312.

13. Bekaert, G., Harvey, C. R., Lundblad, C. T., \& Siegel, S. (2016). Political risk and international valuation. Journal of Corporate Finance, 37, 1-23.

14. Bessler, W., \& Opfer, H. (2004). Bank stock returns and economic variables: an empirical analysis for Germany. In Aktuelle Entwicklungen im Finanzdienstleistungsbereich (pp. 205-219). Physica, Heidelberg.

15. Bhattarai, Y. R. (2014). Determinants of share price of Nepalese commercial banks. Economic Journal of Development Issues, 187-198.

16. Bhattarai, Y. R. (2014). Determinants of share price of Nepalese commercial banks. Economic Journal of Development Issues, 187-198.

17. Bokpin, G. A., \& Isshaq, Z. (2008). Stock market development and financing decisions of listed firms in Ghana. African Journal of Business Management, 2(11), 209-216.

18. Chami, R., Fullenkamp, C., \& Sharma, S. (2010). A framework for financial market development. Journal of Economic Policy Reform, 13(2), 107-135.

19. Demir, F., \& Dahi, O. S. (2011). Asymmetric effects of financial development on South-South and South-North trade: Panel data evidence from emerging markets. Journal of Development Economics, 94(1), 139-149.

20. Demirguc-Kunt, A., Feyen, E., \& Levine, R. (2011). Optimal Financial Structures and Development: The evolving importance of banks and markets. World Bank, mimeo.

21. Duy, V. Q., \& Dang, N. H. (2017) Determinants of Stock Prices of Joint-Stock Companies in Industrial Sector Listed On Hcm City Stock Exchange. International Journal of Advanced Engineering Research and Science, 4(4).

22. Enow, S. T., \& Brijlal, P. (2016). Determinants of share prices: the case of listed firms on Johannesburg Stock Exchange. Journal of Accounting and Management, 6(1), 85-92

23. Gan, C., Lee, M., Yong, H. H. A., \& Zhang, J. (2006). Macroeconomic variables and stock market interactions: New Zealand evidence. Investment management and financial innovations, (3, Iss. 4), 89-101.

24. Gatua, F. K. (2013). Analysis of share price determinants at Nairobi securities exchange. Unpublished MBA Project of the University of Nairobi.

25. Ghimire, R. R., \& Mishra, D. Determinants of Stock Price in Nepalese Market. The International Research Journal of Management Science. 3(1), 124-135.

26. Gill, A., Biger, N., \& Mathur, N. (2012). Determinants of equity share prices: Evidence from American firms. International Research Journal of Finance and Economics, 90(90), 176- 192.

27. Habib, Y., Kiani, Z. I., \& Khan, M. A. (2012). Dividend policy and share price volatility: Evidence from Pakistan. Global Journal of Management and Business Research, 12(5).

28. Humpe, A., \& Macmillan, P. (2014). Non-linear predictability of stock market returns: comparative evidence from Japan and the US. Investment Management and Financial Innovations, 11(4).

29. Khan, M. N. (2012). Determinants of share prices at Karachi stock exchange. International Journal of Business and Management Studies, 4(1), 111-120.

30. Khan, S. H. (2009). Determinants of share price movements in Bangladesh: Dividends and retained earnings.

31. Kuduk, C. A. (2009). Hawking liquidity: an analysis of reverse merergers and SPACS. Journal of Applied Economy, 51-62.

32. Leibowitz, M. L., \& Henriksson, R. D. (1989). Portfolio optimization with shortfall constraints: A confidence-limit approach to managing downside risk. Financial Analysts Journal, 45(2), 34-41. 
33. Magnus, F. J. (2008). Capital market efficiency: An analysis of weak-form efficiency on the Ghana Stock Exchange. Journal of Money, Investment and Banking, 5(5), 5-13.

34. Miller, M. H., \& Modigliani, F. (1961). Dividend policy, growth, and the valuation of shares. the Journal of Business, 34(4), 411-433.

35. Mondal, M. S. A., \& Imran, M. S. (2010). Determinants of stock price: a case study on Dhaka stock exchange. International Journal of Finance, 2(3), 1-16.

36. Musah, A., Badu-Acquah, B., \& Adjei, E. (2019). Factors that influence bond markets development in Ghana. Jurnal Perspektif Pembiayaan Dan Pembangunan Daerah, 6(4), 461-476.

37. Nautiyal, N. (2015). Linkage between Exchange Rate and Stock price: Symmetric and Asymmetric Cointegration.

38. Owiredu, A., Oppong, M., \& Asomaning, S. A. (2016). Macroeconomic determinants of stock market development in Ghana. International Finance and Banking, 3(2), 33-48.

39. Oyama, T. (1997). Determinants of stock prices: The case of Zimbabwe (No. 97-117). International Monetary Fund.

40. Sanju, P. S., Ramachandran, M., \& Nirmala, P. S. (2011). Determinants of share prices in India. Journal of Emerging Trends in Economics and Management Sciences, 2(2), 124- 130.

41. Saunders, B., Sim, J., Kingstone, T., Baker, S., Waterfield, J., Bartlam, B., ... \& Jinks, C. (2018). Saturation in qualitative research: exploring its conceptualization and operationalization. Quality \& quantity, 52(4), 1893-1907.

42. Singh, D. (2018). Stock Price Determinants: Empirical Evidence from Muscat Securities Market, Oman. Firm Value: Theory and Empirical Evidence, 21.

43. Somoye, R. O. C., Akintoye, I. R., \& Oseni, J. E. (2009). Determinants of equity prices in the stock markets. International Research Journal of Finance and Economics, 30(13), 177- 189.

44. Sunde, T., \& Sanderson, A. (2009). A review of the determinants of share prices. Journal of Social Sciences 5(3): 188-192.

45. Wadud, M. (2017). Determinants of Share Prices of Listed Commercial Banks in Bangladesh. Determinants of Share Prices of Listed Commercial Banks in Bangladesh (September 17, 2017). 